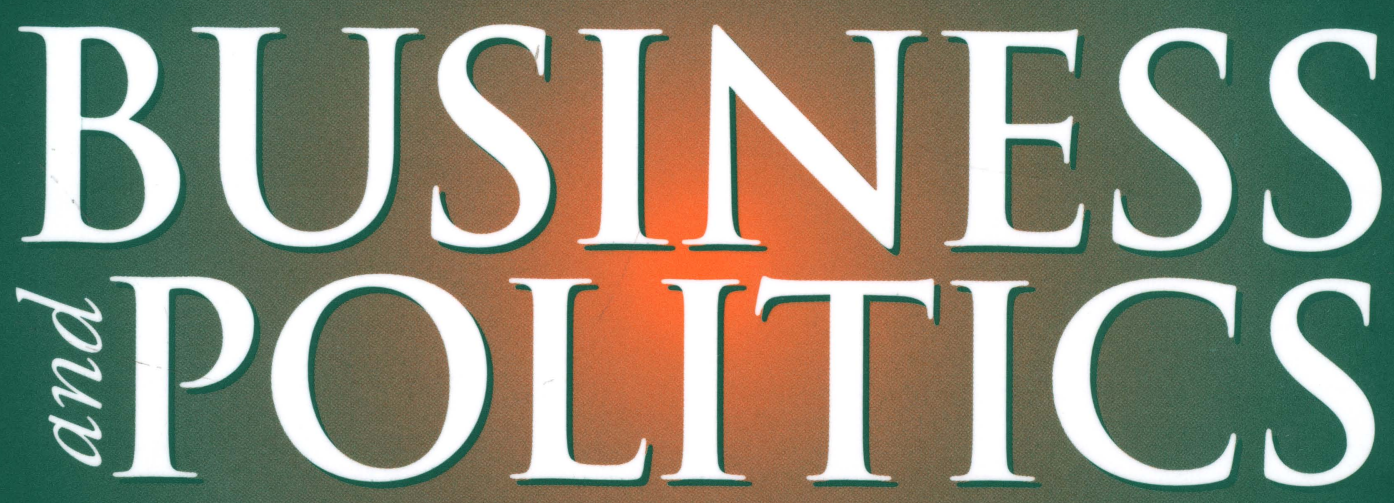




\section{BUSINESS POLITICS}

\section{EDITOR-IN-CHIEF}

Vinod K. Aggarwal, University of California, Berkeley, USA

\section{EDITOR}

Emerson Tiller, University of Texas, USA

\section{ASSOCIATE EDITORS}

Asia and the Pacific

John Ravenhill, Edinburgh University, $U K$

Europe and Africa

Cédric Dupont, Graduate Institute of International Studies, Geneva, Switzerland

Latin America

Maxwell Cameron, University of British Columbia, Canada

North America

Thomas Gilligan, University of Southern California, USA

Cases and Commentary

Douglas Schuler, Rice University, USA

\section{ASSISTANT EDITOR \\ Ralph Espach, University of California, Berkeley, USA}

\section{EDITORIAL BOARD}

Pierre Allan, University of Geneva, Switzerland; David Baron, Stanford University, Stanford, USA; David Besanko, Northwestern University, USA; Richard Buxbaum, University of California, Berkeley, USA; Stuart Chemtob, Attorney, Washington D.C.. USA; Beverly Crawford, University of California, Berkeley, USA; Frank Cross, University of Texas, USA; John de Figueiredo, Massachussetts Institute of Technology, USA; Justin Greenwood, Robert Gordon University, UK; Paolo Guerrieri, University of Rome, Italy; Ronald Gutfleish, HPB Associates, USA; Gary Hufbauer, Institute of International Economics, Washington DC, USA; Merit Janow, Columbia University, USA; David Kang, Dartmouth College, USA; Peter Katzenstein, Cornell University, USA; Robert Lawrence, Harvard University, USA; Joanne Oxley, University of Michigan, USA; Brian Roberts, University of Texas, USA; Susan Rose-Ackerman, Yale University, USA; Richard Shell, University of Pennsylvania, USA; Brian Silverman, Harvard University, USA; Pablo Spiller, University of California, Berkeley, USA; Paula Stern, The Stern Group, Washington, DC, USA; Shu Urata, Waseda University, Japan; David Vogel, University of California, Berkeley, USA; Maria Weber, Bocconi University, Italy; Barry Weingast, Stanford University, USA; Oliver Williamson, University of California, Berkeley, USA; Graham Wilson, University of Wisconsin, USA; Mark Zacher, University of British Columbia, Canada

Business and Politics publishes articles, cases, and commentaries within the broad area of the interaction between firms and political actors. Two specific areas are of particular interest to the journal: 1) The use of nonmarket corporate strategy including internal organizational design decisions as well as external strategies. Internal organizational design refers to management structure, sourcing decisions, and transnational organization with respect to the firm's nonmarket environment. External strategies include legal tactics, testimony, lobbying and other means to influence policy makers at all levels of government and international institutions as an adjunct to market strategies of the firm. 2) Efforts by policymakers to influence firm behavior through regulatory, legal, financial, and other government instruments.

Business and Politics does not favor any particular methodology or approach, but emphasizes analytical rigor and novel empirical analysis. The journal publishes articles that focus on different regions of the world, cross-regional studies, and interdisciplinary work. It strongly encourages perspectives from business, political science, law, economics, and public policy.

Editorial Correspondence should be addressed to: Professor Vinod Aggarwal, Editor-in-Chief, Business and Politics, 802 Barrows Hall \#1970, University of California, Berkeley, California 94720-1970 or bap@socrates.berkeley.edu.

Advertising: USA/Canada: The Advertising Manager, PCG, 875 Massachusetts Avenue, Suite 81, Cambridge, MA 02139, USA. Tel: +1 617497 6514; Fax: +1 6173546875 .

EU/Rest of the World: The Advertising Manager, Taylor \& Francis, PO Box 25, Abingdon, Oxfordshire OX14 3UE, UK. Tel: +44 (0)1235 401000 ; Fax: +44 (0)1235 401550.

Business correspondence, including orders and remittances relating to subscriptions, back numbers and offprints, should be addressed to the publisher: Taylor \& Francis Ltd, Customer Services Department, Rankine Road, Basingstoke, Hants RG24 8PR, UK.

\section{ISSN 1369-5258}

The journal is published three times a year, April, August and November. These three issues constitute one volume. A Volume Contents and Author Index is published in the last issue of the volume. 


\section{SUBSCRIPTION RATES}

Business and Politics, Volume 4, 2002, 3 issues. ISSN 1369-5258

Institutional rate (includes free online access):

$£ 120.00$ US $\$ 199.00$

Personal rate (print only):

$£ 28.00$ US $\$ 40.00$

Subscription rates include postage/air speeded delivery

\section{ORDERING INFORMATION}

Please complete in full the details on the Order Form and return to:

Taylor \& Francis Ltd, Customer Services Department, Rankine Road, Basingstoke, Hants RG24 8PR, UK

\section{OR TO}

Taylor \& Francis Inc, 325 Chestnut Street, 8th Floor, Philadelphia, PA 19106, USA

\section{By fax:}

+44(0)1256 330245 (UK)

+12156252940 (USA and Canada)

\section{By telephone:}

$+44(0) 1256813000(\mathrm{UK})$

+18003541420 (USA and Canada)

\section{By WWW:}

http://www.tandf.co.uk

By e-mail:

enquiry@tandf.co.uk

For further details on the journal, including contents pages, please visit the Carfax Website at http://www.tandf.co.uk/journals

\section{COPYRIGHT}

Copyright (c) 2002 Taylor \& Francis Ltd. All rights reserved. No part of this publication may be reproduced, stored, transmitted, or disseminated, in any form, or by any means, without prior written permission from Taylor \& Francis Limited, to whom all requests to reproduce copyright material should be directed, in writing.

Taylor \& Francis Limited grants authorization for individuals to photocopy copyright material for private research use, on the sole basis that requests for such use are referred directly to the requestor's local Reproduction Rights Organization (RRO). The copyright fee is $\$ 14$ exclusive of any service charge or fee levied. In order to contact your local RRO, please contact:

International Federation of Reproduction Rights Organisations (IFRRO), rue du Prince Royal, 87, B-1050 Brussels, Belgium; e-mail: ifrro@ skynet.be Copyright Clearance Center Inc., 222 Rosewood Drive, Danvers, MA 01923, USA: e-mail: info@ copyright.com

Copyright Licensing Agency, 90 Tottenham Court Road, London W1P 0LP; e-mail: cla@cla.co.uk

This authorization does not extend to any other kind of copying, by any means, in any form, and for any purpose other than private research use.

\section{ABSTRACTING AND INDEXING SERVICES}

Business and Politics is indexed in International Political Science Abstracts and Zeller Verlag (1BZ/1BR).

\section{BUSINESS AND POLITICS}

\section{ORDER FORM}

Please enter my subscription to Business and Politics, Volume 4, 2002, 3 issues, ISSN 1369-5258.

Institutional rate

$\square £ 120.00 \square$ US\$199.00

Personal rate

$\square £ 28.00 \square$ US $\$ 40.00$

Personal subscriptions are welcomed if prepaid by credit card or personal cheque.

\section{METHODS OF PAYMENT}

$\square$ Payment has been made to:

Girobank plc, Bootle, Merseyside GIR 0AA, UK

Sort Code: 72-00-00. Account No: 5513057

Payment has been made by bank transfer to one of the following accounts (please indicate):

UK (Sort Code - 600249 )

National Westminster Bank plc, Old Market Square Branch, 3 London Street, Basingstoke,

Hants RG21 7NS, UK

f Account No: 01484400

US\$ Account No: 01328735

USA

Fleet Bank N.A., 3rd Floor, 1185 Avenue of the Americas, New York, NY 10036, USA

Account No: 9417201589

ABA No: 021200339

Swift Ref: NBNAUS33

Payment enclosed. Cheques or bank drafts should be made payable to Taylor \& Francis Ltd and be drawn on a UK or US bank.

Please charge: $\begin{gathered}\square \text { American Express } \square \text { Eurocard } \\ \square \text { MasterCard } \square \text { Visa }\end{gathered}$

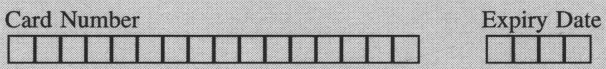

Signature

Date

Our Value Added Tax Registration number is

We are not registered for Value Added Tax

\section{INSPECTION COPY}

$\square$ Please send me an inspection copy of Business and Politics NAME

ADDRESS

POST/ZIP CODE

COUNTRY

TELEPHONE FAX 


\section{BUSINESS AND POLITICS}

\section{Volume 4 Number 3 November 2002}

\section{Articles}

Private Ordering on the Internet: The eBay Community of Traders

David P. Baron

Strategic Responses to Global Climate Change: Conflicting Pressures on Multinationals in the Oil Industry

David L. Levy \& Ans Kolk

Polish Business Associations: Flattened Civil Society or Super Lobbies? Iain McMenamin

Business and the Crisis of Peruvian Democracy

Francisco Durand

Corrigendum

Volume Contents and Author Index, Volume 4, 2002 